\title{
Upper Silesia: The revival of a traditional industrial region in Poland*
}

\begin{abstract}
This paper provides an insight into the transformation processes that have affected Upper Silesia, a Polish border region with long traditions of industrialisation, autonomous structures and volatile historical changes. It shows how the region, profoundly affected by the structural crisis of mining and heavy industry and experiencing unfavourable demographic processes, has managed to recover and prosper under new conditions. In a fragmented space characterised by strong urbanisation, industrial restructuring has been based on the renewal of traditional branches and the creation of new development paths through reindustrialisation and service-based development. The size of Upper Silesia, and particularly the conurbation surrounding Katowice, has also led to attempts at establishing effective metropolitan governance, a challenge whose success depends as much on harmonising internal interests as finding a compromise acceptable by both the region and the central government.
\end{abstract}

Keywords: Upper Silesia, industry, industrial restructuring, regionalism, metropolitan regions.

\section{Introduction}

As one of Poland's six historical regions (Koter-Kulesza 2003), Silesia ${ }^{1}$ has changed ownership multiple times since the formation of the Polish state, not least due to its position along the border. After Poland's final partition in 1795, it became a borderland among three empires - Prussia, Russia and the Habsburg Monarchy. After World War One, the western part of Upper Silesia was awarded to Germany, while its eastern part came to be divided between the newly independent Poland and Czechoslovakia. The

a) HAS Research Centre for Economic and Regional Studies Institute for Regional Studies, H- 7621 Pécs, Papnövelde u. 22., Hungary. E-mail: baranyain@rkk.hu

b) HAS Research Centre for Economic and Regional Studies Institute for Regional Studies, H- 7621 Pécs, Papnövelde u. 22., Hungary. E-mail: lux@rkk.hu

* This paper has been supported within the TÁMOP-4.2.2.A-11/1/KONV-2012-0010 project (The automotive industrial district of Györ as the new direction and method of regional development). Gábor Lux has been supported by the János Bolyai Research Scholarship of the Hungarian Academy of Sciences, while Nóra Baranyai has been supported by the Erdős Pál Young Research Scholarship within the framework of TÁMOP 4.2.4.A/2-11-1-2012-0001 key project at the time of publication. The authors would like to thank Krzysztof Gwosdz and the paper's anonymous reviewers for their valuable criticism and suggestions.

${ }^{1}$ The western part within Silesia, Lower Silesia and the eastern part, Upper Silesia have been distinguished since the $15^{\text {th }}$ century (Malloy 2005). 
territorial administrative unit belonging to Poland, named the Silesian Voivodeship, was the most developed, most industrialised ${ }^{2}$ and most culturally diverse region of the country. Its autonomy was guaranteed by the Polish state - de facto until 1939, but nominally until $1945 .^{3}$ With the shifting borders after World War Two, the remaining areas of Upper Silesia and the majority of Lower Silesia were also annexed by Poland.

The present Silesian Voivodeship, in existence since 1999, is now one of the smallest, although, after the capital region of Masovia, the second most populous region in Poland (4.6 million inhabitants as of 2011). The high population density is mainly due to the region's degree of urbanisation, the development policy of state socialism, and the associated migration processes. The Katowice conurbation ${ }^{4}$ has a population over 2 million, and along with the Voivodeship's sub-centres, has an urbanisation ratio of $77.7 \%$, significantly outstripping the national average (60.7\%). The Voivodeship belongs to the most developed regions of the country; third by per capita GDP, and fifth by per capita investments. It is also ranked high by statistics related to economic development and competitiveness; second after Masovia according to the number of employees and gross incomes and third according to the level of unemployment. It is in demographics where its situation is less favourable: it is in eleventh place by both natural population growth and the balance of migration.

This paper seeks to review the contemporary transformation processes and development issues of the Upper Silesian Voivodeship. As one of the most populous and highly urbanised regions in post-socialist Central Europe, with an economy that has been emerging from a deep structural crisis, Upper Silesia presents both enormous development potential and significant challenges. The region is slowly re-establishing itself as one of Poland's leading industrial and commercial hubs, and an integrating cityregion, which can compete on the European level. In the paper, some of the main aspects of the region's territorial development have been summarised, with regards to its unique socio-economic characteristics, urbanisation patterns, economic restructuring processes and the challenges of polycentric governance. To this end, the authors have relied on literature review, extensive field research within the region (undertaken in 2007, 2013 and 2014), as well as the regional statistics. These highlight the Voivodeship's special position with respect to Poland and broader Central Europe. Attention is also payed to its significant and persistent internal differences.

\section{Demographic characteristics}

The Voivodeship has significant intra-regional differences in the realm of demographics and social indicators. Population is the highest in the conurbation and regional subcentres; the most prominent is Katowice, the centre of the Voivodeship $(310,764$

\footnotetext{
${ }^{2}$ The area, formerly belonging to Prussia, underwent rapid modernisation, with the first steelworks being erected in 1794 (Davies 2006), followed by the emergence of an industrial region, which was the second in Germany after the Ruhrgebiet (Szczepański-Śliz 2012).

${ }^{3}$ The Silesian voivodeship had an independent parliament, representing a legislative and fiscal autonomy disposing over ca. one half of local tax revenues through its own treasury (Szczepański-Śliz 2012, Bialasiewicz 2002).

${ }^{4}$ The Polish Statistical Office delineates the conurbation as a group of 19 cities in the centre of the region, while the government of the Silesian voivodeship considers it to consist of 14 cities.
} 
inhabitants), followed by Częstochowa (236,796), Sosnowiec (216,421), Gliwice $(187,475)$, Zabrze $(181,128)$ and Bytom $(176,902)$. The region's least inhabited territory is the broader Częstochowa area, occupying the northern part of the Voivodeship (Figure $1)$. The population density $\left(375 \mathrm{p} / \mathrm{km}^{2}\right)$, more than three times the national average, conceals significant regional differences, since the value is 510 per $\mathrm{km}^{2}$ in the core area, while only 175 per $\mathrm{km}^{2}$ around Częstochowa. The record of the conurbation is held by Świętochłowice with $4165 \mathrm{p} / \mathrm{km}^{2}$, occupying first place in the entire country.

Figure 1

Population level in the gminas of the Silesian Voivodeship, 2011 (inhabitants)

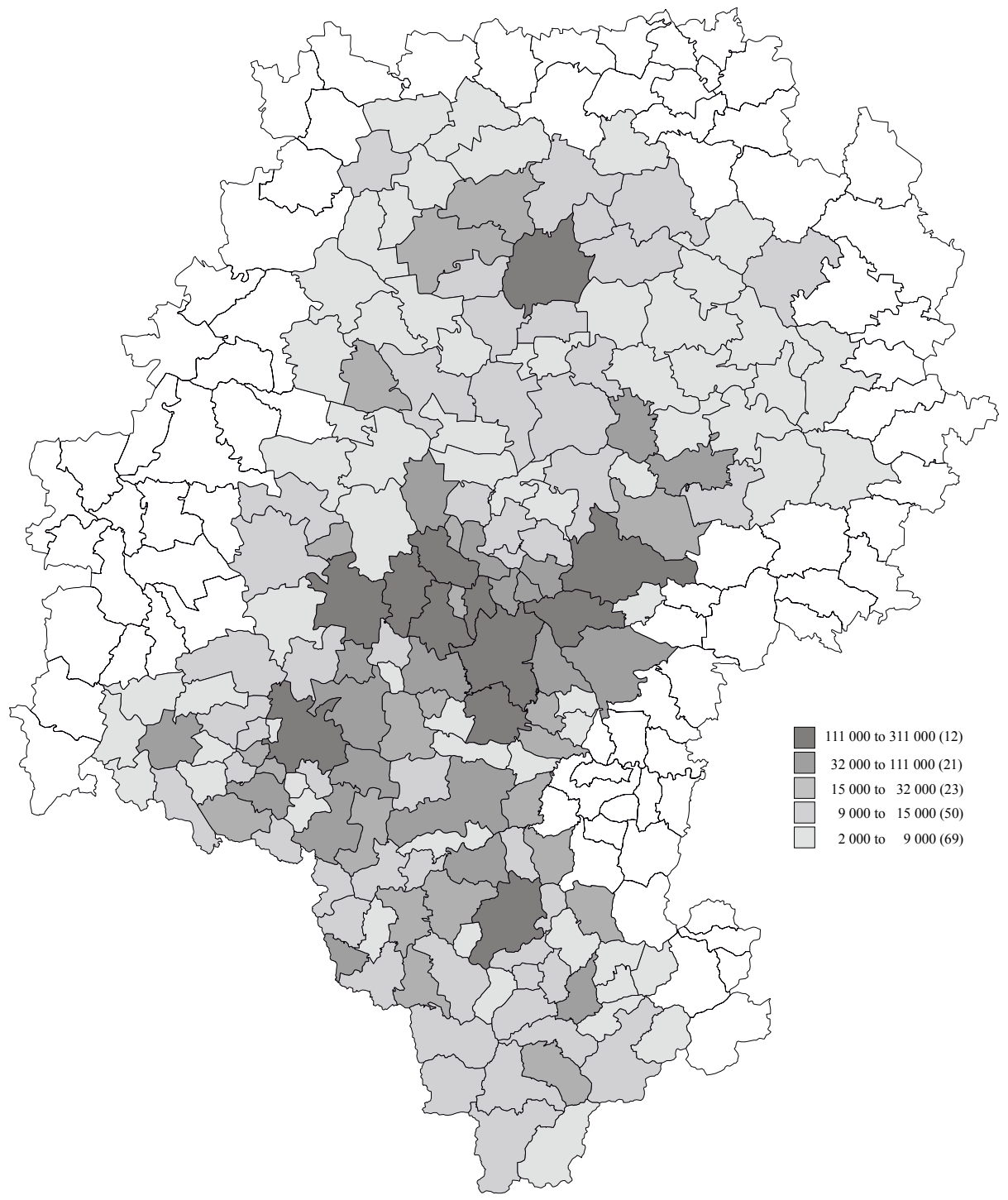

Source: author's construction based on GUS. 
Unlike other states in post-socialist Central Europe, Poland has experienced a population increase in recent decades, although this process is reversed in two old industrial regions, the Łódź and Silesia voivodeships. According to the processes of industrial restructuring, there has been a continuous and severe population decline in the area since 1989. All cities within the voivodeship have been losing population, but not in equal measure - while the figure is $15-17 \%$ in the conurbation, it is only about $2 \%$ in the sub-centres (Rechlowicz-Tkocz 2013). The largest decline at the powiat level can be seen in Bytom, struggling with significant socio-economic problems: between 2002 and 2011 , almost 17 thousand people, or $8.6 \%$ of the population has been lost. In some rural areas (e.g. the Bielskie and Gliwicki powiats), increasing population can be observed due to suburbanisation processes (Figure 2). In the case of the conurbation and Częstochowa, the target of migrations is not the immediate surroundings of the city, but more distant areas such as the Bielskie powiat - representing a process of "external suburbanisation" (Runge-Klosowski 2011).

Figure 2

Population change in the gminas of the Silesian Voivodeship, 1995-2012 (inhabitants)

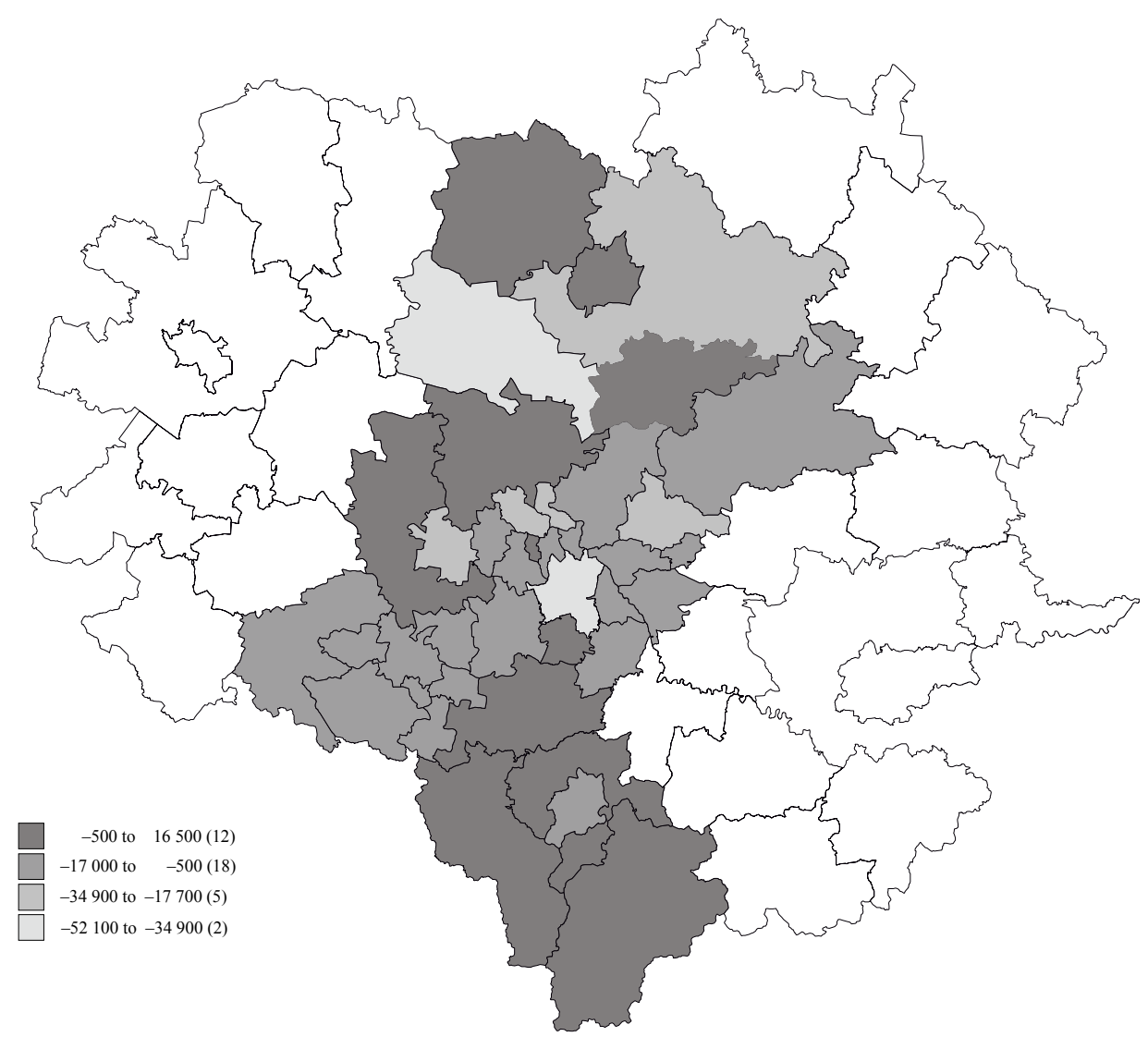

Source: author's construction based on GUS. 
The declining population of the voivodeship, and particularly the cities, is based on the joint effects of natural decrease and negative migration balance. The region is characterised by ageing, with less and less births and children. Intra-regional differences are shown by the rapid decline of the central and northern areas, as well as the natural growth of the southern and western powiats. A negative migration balance is mainly found in cities, particularly in the conurbation while a positive net outcome can be observed in the rural north and south. The negative results can only be partially explained by the suburbanisation process, as economic restructuring plays a role which is at least as relevant. Migration to former hometowns and emigration to find work abroad has become commonplace (Rechlowicz-Tkocz 2013). Therefore, the voivodeship has a negative migration balance in both the domestic and international sense: favoured targets include the neighbouring Małopolska Voivodeship as well as Germany and Great Britain. The problems related to demographics are compounded by the fact that migration occurs most often among the young, which accelerates the natural decline; this is forecasted to be $12.4 \%$ population loss by 2035 according to the GUS (Strategia...2013). Although the Silesian Voivodeship remains a target of migration from other Polish regions, especially from the centre and western part of the country (Łobodzińska-Zbiorowski-Soja 2012), this process cannot counteract the basic declining trend.

In the last decade, the number of children has significantly decreased in the voivodeship $(-2.7 \%)$, while there was an increase in the number of elderly $(+2.3 \%)$. The ageing index shows that the processes pose a problem for Katowice and the cities in particular while south of the conurbation, including suburbanised areas, the ratio of the two generations is more balanced. Meanwhile, the population of the voivodeship has improved its educational levels since 2002: the ratio of people with only basic education has fallen from $28.7 \%$ to $16.7 \%$, while there has been an increase in the number of graduates,improving from 8.9 to $15.9 \%$ of the population. Higher education shows territorial concentration in the cities, while basic education is more prevalent in rural areas.

\section{Fragmented metropolis}

Silesia's early industrialisation, followed by its uncontrolled growth in the $19^{\text {th }}$ century and multiple layers of urban planning in the $20^{\text {th }}$, has created a highly urbanised spatial structure. In the European context, it is closest to the Ruhr and (to a lesser extent) coaland-steel regions in Great Britain. Urban development was simultaneously characterised by traditional city growth (with some centres such as Bytom, Gliwice, Cieszyn or Racibórz having an urban past going back to the $12^{\text {th }}$ century); conscious urban development policy following Prussian, Polish and later socialist ideas (Katowice, Dąbrowa Górnicza, Tychy), and sprawl around the sites of mining and industry, consisting of very heterogeneous, often functionally poor and spatially isolated workers' colonies. The main quality of space is strong fragmentation: settlement components with widely divergent origins, physical quality and level of maintenance are found haphazardly in each other's proximity. The conurbation, emerging from constituting cities but also bearing some traits of a single metropolis, carries this heterogeneity on all 
territorial scales. We can speak of fragmentation in the following dimensions of spatial differentiation:

- Despite large-scale population movements, historical tragedies and homogenisation attempts, Upper Silesia is still characterised by the legacies of Poland's threefold imperial division. The different cultural and socio-economic attributes of the Prussian, Austro-Hungarian and Russian zones of influence are in evidence even today. They can be seen in the weaker institutional endowment but higher formal education in the conurbation's eastern population (e.g. the Dąbrowa basin), or the more advanced technological competencies of the western, formerly Prussian parts.

- The Silesian Voivodeship itself is sharply differentiated: the conurbation, Częstochowa, Rybnik's coal mining district and Bielsko-Biała are three disparate poles within a single voivodeship (Klasik-Heffner 2001), and a source of both structural and political divisions. The disproportionate scales are in a sense similar to the Hungarian urban network: the conurbation's 2.7 million inhabitants are scarcely counter-balanced by the smaller cities, which have a population of 176-240 thousand inhabitants. It is this difference in magnitude that unequivocally tips the balance of power towards the urbanised core.

- The differences that subdivide the conurbation originate from the cities' different development paths, as well as the socio-economic and institutional changes taking place on the level of the conurbation after the change of system. Despite multiple integration attempts, the conurbation remains politically divided, and the independent policies of local governments lead to parallel developments, overlapping competencies and constant conflict.

- The cities are fragmented by the mining and industry-driven urbanisation process, leading to a non-standard urban morphology characterised by very diverse housing stock. This was further differentiated by the later processes of social breakdown, industrial crisis, environmental and mining damage, and followed by market-led and community-based revitalisation initiatives). Radical differences are found even on the level of individual housing blocks, making for a mosaic-like spatial pattern.

The fragmentation of the urban fabric is not merely a phenomenon of space, but one which is also embedded in the temporal dimension. The rapid succession of empires, external dependencies and ideologies have oriented decision-makers towards radical urban planning. Development and destruction (city-building and intentional citydemolition) have been based on the free overwriting of symbolic spaces, and sometimes entire urban functions. Even today, city morphology remains influenced by the outcomes of previous decisions (Murzyn-Kupisz-Gwosdz 2011, Chmielewska 2012), including

- the time of the threefold imperial division, particularly the city architecture and urban planning of the German Empire, embodied by the period's modern housing estates and city centres, and representing the "civilising power" of Teutonic culture within the idea of the "little big city"s;

\footnotetext{
5 „Berlin - Eine große Großstadt! Breslau - eine große Kleinstadt! Kattowitz - eine kleine Großstadt!” (cited by MurzynKupisz-Gwosdz 2011, p. 115.)
} 
- the German-Polish division between the world wars, where the Polish side saw fit to construct an independent, modern Polish identity on the basis of renouncing "Germanness" through adapting contemporary architecture on the basis of the American ideal;

- the Nazi occupation, consciously demolishing the Polish built landscape, followed by the "de-Germanisation" of the conurbation's architectural heritage, ${ }^{6}$

- state socialism, linking the spaces of production to representative, monumental building complexes (housing estates, processional squares and sport halls) while other central elements of urban space became "emptied-out", stripped of their former relevance with the downsizing of consumption and trade, or in the case of living areas, "overwritten" by newly erected living complexes;

- modern Upper Silesia, where the re-formed spaces of consumption, business services and finance have led to the emergence of a Central Business District in Katowice, while other urban centres in the conurbation have contributed to this reclaiming of the city with the rise of representative shopping centres and malls. ${ }^{7}$

The present development of the city-region shows a dual trajectory: on one hand, individual cities undergo specialisation; on the other, there are attempts by governance at setting down common goals at a metropolitan level, transforming the legacy of fragmentation into the modern European virtue of polycentric development. From the cities competing for leadership, Katowice has proven to be the strongest, gradually establishing itself as the de facto centre of not just the region, but the conurbation as well. Other significant cities (particularly Gliwice, Sosnowiec and Tychy) take on the role of sub-centres in this configuration. There are signs that this polycentric urban entity might return to the "traditional" path of city development, transforming itself into a monocentric agglomeration, then Poland's largest city - although this possibility is made harder by Katowice's small population weight within the conurbation, with only $15 \%$ of all inhabitants (Mikołajec 2008). ${ }^{8}$

The renewal of central urban spaces continues to show a lopsided picture. In Katowice, only the last few years have seen the regeneration of the historical city centre, based on the conversion of spaces formerly used by transportation or industry, and attempting to create a functional city centre. The underlying consumption-oriented model relies on private capital as well as European Union funding, and fits into the mainstream of European urban policies. Pedestrian zones, bicycle paths and shopping streets, reconstructed with the aid of EU money; the renewal of the central railway station of

It would be difficult to find a better symbol here than the Silesian Parliament (today the Marshall's office and the seat of the voivodeship government): constructed as a counterpoint to the "German Gothic", its massive neo-classical complex was seen to be representative of the voivodeship's wealth and power in 1929, it was almost naturally converted into a centre of the Reich administration during the Nazi occupation by removing the traces of Polishness. Later, it once again came to be a centre of the Polish state apparatus, but a rival, equally impressive building was erected across the square as the headquarters of the Polish Workers' Party. After 1989, the symbolic space was reclaimed once again - by constructing monumental statues for two great interwar statesmen, Józef Piłsudski and Wojciech Korfanty.

${ }^{7}$ The first representative of the enormous shopping complexes, Silesia City Centre has been constructed by the Hungarian TriGránit group on the site of the former Gottwald mine as a brownfield project, preserving and rejuvenating certain symbolic elements of the mine's architectural ensemble as a reminder of the city's heritage.

${ }^{8}$ It must be mentioned, however, that Katowice concentrates $1 / 4$ of the conurbation's employment and $1 / 2$ of its high valueadded services. 
Katowice and the building of a connected shopping mall; or the currently emerging new cultural quarter on former mine sites (a concert hall, exhibition space, university library and conference centre) enrich the city with previously missing metropolitan-scale infrastructure and new public spaces. The transformation contributes to economic diversification and has positive consequences for socio-economic resilience (Polko 2012). However, the projects also carry basic contradictions. Local ambitions require the building of large shopping centres in every city (Polko 2013) - symbols of modern urban pride - but the development of the central city is not followed by organic renewal and functional enrichment throughout the broader conurbation. Rather, renewed urban areas almost always border on smaller or larger areas of segregation, functional hollowing-out and brownfields that remain unintegrated. Entire cities (e.g. Bytom) are affected by mining damage to the housing stock or migration losses. The allocation of public funds for urban renewal, as well as its overall distribution within the conurbation, becomes a matter of strategic significance. The most important problem of development might in fact be an opportunity cost on the level of ideas - in the future ambitions of the conurbation, formerly existing bold and innovative ideas of economic development have given way to the schematic copying of mainstreamed European urban policies. The objectives and funding of common development policy uniformise thinking as much as action, and the example of the cultural quarter in Katowice shows that these ideas are often identical to those found in any other large city in Europe - while local conditions would prescribe an entirely different way of development.

\section{The space-forming effects of the old and new economy}

As a prime example of Old Industrial Regions (Lux 2009), the economic structure of Upper Silesia was characterised by the excess weight of traditional industrial branches and the underdevelopment of services at the time of systematic change. In 1990, the Voivodeship (then divided among three territorial units) had 1.2 million inhabitants employed in industry, of whom 415 thousand (35\%) had been working in coal mining, and 103 thousand (8.7\%) in the steel industry. In contrast, the entire tertiary sector had only 814 thousand employees or $34.5 \%$ of total employment. Over recent decades, the direction of restructuring has been towards the tertiary patterns commonly found in Central Europe (Figure 3), although, the process proved to be less thorough than in other industrial regions. Similar to the agglomeration of Ostrava-Karviná on the Czech side of the border, services could only absorb a limited number of the workforce that suddenly appeared on the labour market (Sucháček et al. 2012). The continuing significance of industry demonstrates the enormous weight of Upper Silesia's industrial legacy - but apart from the magnitude of the crisis, it also showcases its unexpected resilience in finding new, innovative paths of adaptation. 
$\%$

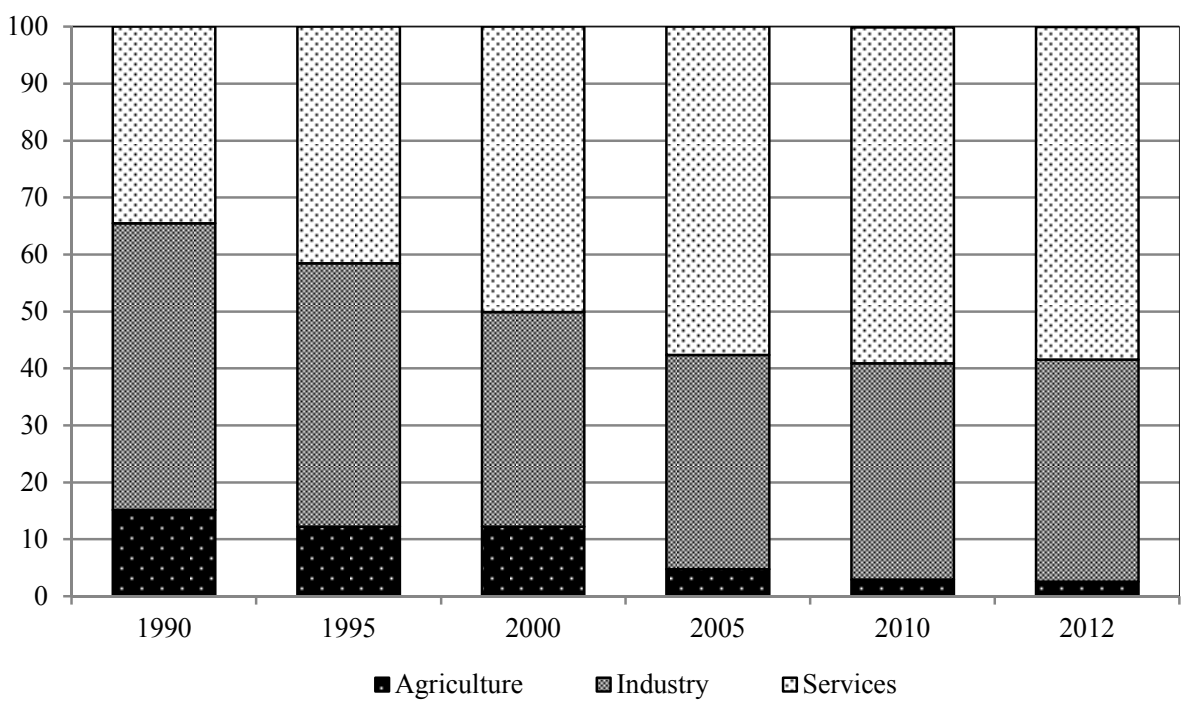

Source: author's construction based on regional statistical yearbooks.

The pace (and limits) of restructuring are shown by the trend lines of workers in coal mining and students in higher education: the first had shown monotonous decline, the second a continuous increase, crossing each other at 135 thousand people in 2002. However, no significant shift has taken place since: the differences between the two groups remain small, and during the crisis, coal mining has even improved its attractiveness. The quality of higher education could not keep up with the development of the city; therefore, the Gliwice Technical University is the best in Upper Silesia, but only the $20^{\text {th }}$ in a national comparison (Gwosdz 2014). De-industrialisation ran its course between 1990 and 2000; since then, its share in employment has been stable around 38\% ( $21 \%$ in Poland), with its share in value added at 35\% (25\% in Poland). The Voivodeship concentrates $17 \%$ of industrial sales, which is only outstripped by the central region of Mazowieckie, which benefits from a strong headquarters effect. Nonetheless, these three core statistics conceal substantial structural renewal on the level of both industries and territorial units.

Miners, helped by strong unionisation and their political capital after 1990, could protect their collective interests and the dominance of public ownership over multiple restructuring programmes (Zientara 2009), while the steel industry adopted a model of relatively more rapid privatisation, and downsizing through early retirement packages and (less successful) retraining schemes (Trappmann 2011) - with more divergent outcomes than coal mining. Traditional branches kept their role in the Upper Silesian economy, but in a different spatial structure. Both coal and steel have undergone organisational and territorial consolidation; retreating from large urban centres and smaller, less economic or technologically obsolete sites. Four state-owned companies 
have remained in coal mining, operating 30 pits, and one private enterprise with one more. In mining, the agglomeration of Rybnik (and particularly the city of Jastrzębie Zdrój) has become prominent, and in the last few years, there have been attempts to reopen mining in Moravian Silesia. In Czechia and Slovakia, the decline of mining was much more radical, but the workforce and capital of Polish enterprises created new opportunities for coal production.

The stronger marketisation of the steel industry has taken place under significant fluctuations on the world market. Unlike coal mining, representing one-half of EU-level production and responsible for $95 \%$ of power generation in Poland, steelmaking only has an EU market share of 5\%. This results in a more competitive business environment from both European companies, and increasingly, from the BRICs group. Transformation took place over multiple waves of buyouts; first through domestic consolidation (during which the number of employees decreased to $42 \%$ of its original value by 1997), and later with the involvement of professional investors from abroad. The largest investment involved the sale and modernisation of the largest steelmaker, Huta Katowice in Dąbrowa Górnicza. With this sale, the investing ArcelorMittal group acquired two-thirds of Polish steel industry revenues and employment. The shock of the 2008-2009 downturn had shaken the industry, culminating in a new consolidation process involving further downsizing (Katarzynat-Ślusarczyk 2010, Ślusarczyk-Kot 2011, Pałucha 2012).

The knowledge and human capital that had been developed in coal mining, heavy and chemical industries also led to the exploration of new development paths, especially new industries on the basis of coal or metalworking. Examples include innovative cluster development on the basis of clean coal technologies; modern environmental industry drawing on the results of land reclamation efforts and chemical industry (SmolińskiPichlak 2009); or Dąbrowa Górnicza's steel industry cluster, focusing on highly processed, high value-added production. The role of proximity is dominant in these new initiatives, and they are often organised as the spin-offs of larger companies, entering the market by exploiting their capital, business connections and production traditions.

Restructuring also has also led to the strengthening of new industries. Former traditions of vehicle manufacturing (Chorzów-Alstom Konstal 1864, Bielsko BiałaPolski Fiat 1971, Tychy-Polski Fiat 1975) and expertise accumulated in the metal industry have been converted into modern know-how through the inflow of Foreign Direct Investment. Special Economic Zones, founded through a local initiative and developed into a country-wide network by being adapted as national development policy, have played a crucial role in attracting and organising investment activity. The zones, resembling industrial estates with multiple sites, first provided generous tax benefits, but due to EU pressure, have gradually switched to direct incentives. The attractiveness of SEZ sites is also based on their location, professional investment promotion, and the quantitative and qualitative advantages of the labour market (Gwosdz-JarczewskiHuculak 2008, Lux 2008, Mezei-Schmidt 2013). The Katowice Special Economic Zone, which extends to the territory of Opole Voivodeship, has been successful in all respects: with 232 companies, an investment volume of $€ 5$ billion and employment of over 51 thousand people, it has shown vigorous growth even under the current crisis (in 2007, capital investments amounted to $€ 2$ billion, and employment to 25 thousand people). 
With a broad spectrum of industries, the dominant branch is the vehicle industry with $62 \%$ of invested capital, - companies mainly from the USA and Italy (GM, Fiat, Isuzu and their suppliers; www.paiz.gov.pl). Through capital investments, the integration of Katowice and Kraków has become the centre of the Polish automotive industry, relevant not just because of its territorial concentration (concentrating 32\% of domestic employment), but also the increasing diversity of companies and activities (end product manufacturers, suppliers, integrators, linked industries and R\&D). Supplier networks were originally based on the privatisation of former state-owned FSM subsidiaries or brought in by foreign investors. However, there is an improving tendency of local added value, and the orientation of domestic suppliers, originally dependent on a single company, has also shown diversification as the industry shows increasing territorial embeddedness. The automotive industry, similarly to other regions in Central Europe, has shown strong resilience in the last years, and was able to improve its performance even during the recession - although the advantages were mainly captured by foreign companies. The relatively high development level, high wages and organised labour of Upper Silesia makes it less vulnerable to the lock-in of low value-added specialisation; and through industrial upgrading, it can weaken the centre-periphery relationships of FDI-dominated industrial development. These relatively high-road strategies also carry some risks: the delocalisation of cost-sensitive manufacturing activities may develop into a more serious issue over time (Domański-Gwosdz 2009, Domański-Lung 2009, Gwosdz-Micek 2010, Domanski et al. 2013).

In post-socialist Central Europe, the development prospects of the high value-added post-industrial economy tend to be limited outside national capitals and their surroundings (Lux 2010). Katowice and its conurbation represent an exception, offering a scale where it can compete in the field of developed business services on a European level. This is shown by the relatively fast growth of the region's banking and services sector. Although the employment share of modern service activities puts Upper Silesia in Poland's middle rankings, its size gives it the largest mass after the Masovian Voivodeship. Some $11 \%$ of employment in finance and insurance, and $10 \%$ of infocommunication activities are located in the region, encompassing both international and domestic actors. Commercial and cooperative banks have settled in the region not merely as the branches of national networks, but have developed significant central functions, or operate as independent subsidiaries (e.g. ING Bank Ślaski, with deep roots within the region even before being acquired by ING). In addition to a large residential market, growth in banking is spurred on by the business sector. In the last decade, local companies' needs for sophisticated financial services had also been supplemented by the opportunities of business process outsourcing. The champions of this branch are Warsaw and Kraków (Gál-Sass 2009, Micek-Działek- Górecki 2011), but BPO centres have also proliferated in Katowice, becoming successfully representatives of the new service sector (Drobniak-Kolka-Skowroński 2012). Even under state socialism, Katowice was a host to trade fairs (and before the war, it had an American-style skyscraper), but it is in these years that it can fully realise its ambitions as a new Central European business centre.

Higher education in the conurbation is divided among four large universities (University of Silesia - 32 thousand students; Gliwice University of Technology 28 thousand students; University of Economics in Katowice - 15 thousand students; 
Silesian Medical University - 9 thousand students) and numerous private colleges mainly focused on business studies. Demographic change has oriented the sector towards institutional consolidation: the three largest universities have lost 16 thousand students over a decade, reversing the boom of the 1990s and early 2000s, and many of the colleges must face a dearth of applications. In the same picture, we can speak of the expanding role of university-business cooperation. Knowledge transfer institutions, sectoral cooperative programmes and business incubators (e.g. Technopark Gliwice, Sosnowiec Science and Technology Park) have extended the role of universities beyond providing skilled labour, playing a role in the local embedding of automotive and machine industry, and upgrading towards higher value-added forms of competitiveness. The relevance of corporate (mostly applied) research is shown by the fact that with the exception of the Podkarpackie Voivodeship (whose values are a statistical anomaly due to few publicly funded research positions), it was Upper Silesia which had reached the highest share of private contribution to R\&D expenditures in Poland (45\%).

The location of traditional and new branches reconfigures the conurbation's economic centres of gravity (Figure 4). Katowice has been particularly successful in the development of modern business services; in addition to the spaces of consumption, we are witness to the formation of an American-style central business district (CBD), integrating surrounding cities through commuting links. In the broader conurbation, evidence can be seen of both successful and failed restructuring. Outside Katowice, it is mainly not the highly tertiarised centres (Bytom, Chorzów, Świętochłowice, Piekary Śląskie) that have managed to keep or improve their positions, but rather cities, which have successfully transformed their former industries or benefitted from reindustrialisation (Tychy, Gliwice, Sosnowiec and Dąbrowa Górnicza; DrobniakKolka-Skowroński 2012, Goczoł 2012, Gwosdz 2014). This situation - like in many other cases across Central Europe - shows that systematic adaptation tends to be a more successful development path than radical restructuring strategies. The emerging functional differentiation of the conurbation appears to support the unification hypothesis. Here, it is not the parallel development paths of the individual cities that will be most important (as it was the case before 1989), but the common framework of an emerging city-region, where the administrative and business centre of Katowice will integrate other cities with varied forms of restructuring, including hubs of strong industrial specialisation. 
The branches and territorial structure of the economy

in the Upper Silesian conurbation, 2010

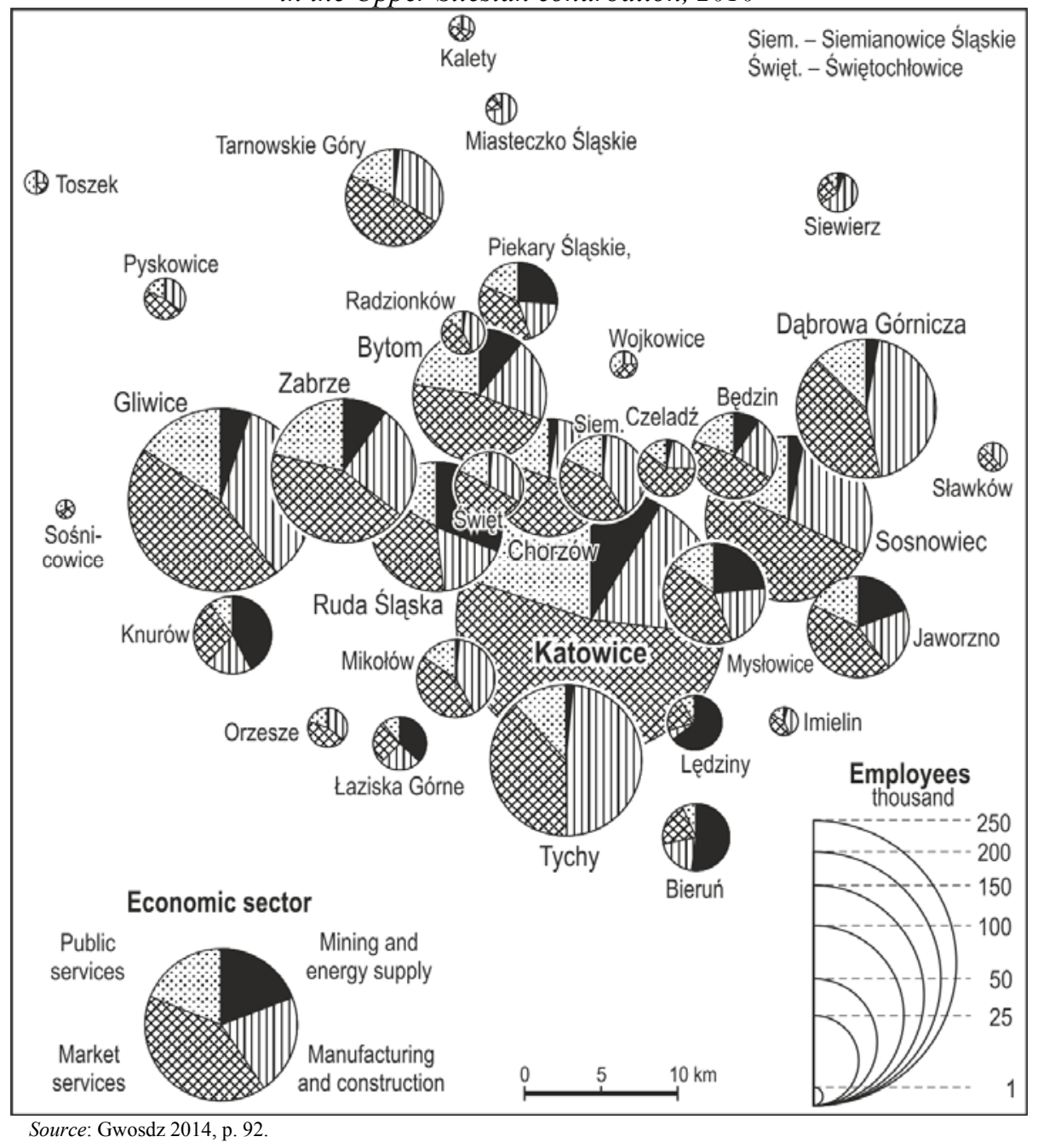

Regional policy structures: a region in search of its governance

After systematic change, with local governments created in 1990, Poland preserved its two-tiered administrative system, which had been in existence since $1975^{\circ}$; it was only in 1998, when a comprehensive administrative reform could be carried out. Detailed

${ }^{9}$ In fact, a third tier, districts had already appeared by this time, although this was not a "genuine" tier of public administration due to its supplementary nature. Created to reduce the administrative burden of voivodeships, districts were disbanded in 1999. 
legislation on territorial governance was set down in the "Small Constitution" of 1992, followed by the Constitution of 1997, declaring municipalities to be the basic units of territorial governance, and delegating the establishment of further units to the level of laws (Const. 1997 Art.70.4.). Accordingly, the 16 voivodeships and 380 powiats created since that time are not named in the Constitution, and do not enjoy its protection.

The Silesian Voivodeship was established in 1999 by merging the former BielskoBiała, Częstochowa and Katowice voivodeships. The Voivodeship has a dual structure in the administrative sense, forming a single NUTS 2 region and encompassing eight NUTS 3 statistical sub-regions, 17 administrative districts (powiats) and 19 cities with district rights (LAU 1), as well as 167 municipalities (LAU 2) - of which 49 are urban, 96 are rural and 22 are mixed local governments. In addition to the Katowice conurbation, three more agglomerations are found in the voivodeship: Bielsko-Biała, Częstochowa and Rybnik. There have been two rather different concepts for the transformation of the existing voivodeship structure.

Upper Silesian Metropolitan Association (Górnoślaski Zwiazek Metropolitalny)

The delineation and creation of metropolitan areas were made possible by the 2003 act on land-use planning and regional development, defining them as the sum of large cities and their functional areas. The ten metropolitan areas ${ }^{10}$ were set down according to specific criteria, but no concrete borders were identified in either the concepts or national legislation, leaving this task to the representatives of the individual regions.

The Upper Silesian Metropolitan Association was created as an organisation based on polycentric foundations and a common system of administration and development, with a main task focused on coordinating development activity (Gorzelak 2005). The charter of the Association, accepted in 2007, was passed by the common action of 14 cities with district rights. The development strategy, building on the socio-economic diversity of the constituting cities, as well as the region's resources (human capital, natural assets, infrastructure and finances), aimed at establishing a metropolitan area which would be competitive on a European scale.

Cooperation was made more difficult by the fact that local governments found it hard to give up their legally guaranteed independence and broad competencies, and the association was burdened by the inevitable conflicts of resource distribution and internal competition. The region's heterogeneity, and the resulting lack of accord was well demonstrated in the debates concerning the name of the future metropolis. Naming it after 'Katowice', the most socially and economically important city, was unacceptable by the other member cities, while 'Silesia' was opposed by the Silesian territories outside the region and the Dąbrowa basin (Szczepański et al. 2013). The compromise, which had emerged by 2009 (Górnośląsko-Zagłębiowska Metropolia "Silesia") was respectful of every party, but clearly unsuitable for its intended purpose.

Furthermore, the establishment of a functional metropolitan association (e.g. in the field of administration) is also opposed by the voivodeship government, and similar

\footnotetext{
${ }^{10}$ Warsaw, the Upper Silesian Agglomeration, Kraków, Łódź, the Three Cities (Gdańsk - Sopot - Gdynia), Poznań, Wrocław, the dual pole of Bydgoszcz and Torun, Szczecin and Lublin.
} 
concerns are voiced on the national level, wary of strengthening rivalry between Warsaw and Upper Silesia, where Katowice and its surroundings, according to size, traditions and contemporary opportunities, might as well prove triumphant. In the battle between rational and emotional reasoning, the latter seem to dominate, and cooperation - which would mean a step forward particularly in solving common problems, especially in infrastructure - is only functioning on the level of a few communal services (Chmielewska - Szajnowska-Wysocka 2010).

\section{Silesian Autonomous Voivodeship (Śląskie Województwo Autonomiczne)}

The multi-ethnic character of the Silesian region remained, but while previously the German nationality was significant throughout Upper Silesia, it is no longer legally recognised ${ }^{11}$ Silesians form the largest group (Silesian is also the largest community with a non-Polish identity - 846,719 people in 2011 - at the national level). With 722,143 people (15.6\% of the region's population), the Silesian identity is most remarkable in the Silesian Voivodeship (USK 2013). In 1990, one subgroup of Silesians founded the Movement for Silesian Autonomy (Ruch Autonomii Ślaska) in Rybnik. Since its foundation, the RAŚ has been demanding the restoration of the region's former autonomous status and governance on the basis of the decentralised model of 1920-1945 (de facto 1920-1939). The background of the initiative is the "unjust" allocation of public funds, namely that Upper Silesia produces $35 \%$ of the national income, but only receives back 2-3\% (Majcherkiewicz 2005). In 2010, the year of its political breakthrough $^{12}$, the RAŚ changed its platform in favour of modernising the Polish state through full decentralisation. On the twentieth anniversary of local government reform, they advocated the creation of a regionalised state consisting of autonomous voivodeships. The initiative set 2020 as the target date to achieve further decentralisation and the autonomy of Upper Silesia.

The proposed constitutional amendment prepared by the party follows the Spanish model: the statutes containing the organisation, tasks and competences of the autonomous voivodeships are based on the principle of asymmetric decentralisation, creating an opportunity for different degrees of devolution for different regions. The plan would repair the missed opportunity of the 1997 constitution, providing a constitutional status not just for municipalities, but powiats and autonomous voivodeships. In addition to reorganising the regional distribution of power, RAŚ would also transform the upper chamber of the bicameral legislature, turning it from a party-dominated organ into an assembly based on the territorial principle. The constitutional plan identifies the tasks of autonomous voivodeships on a much broader basis but does not dictate general responsibilities: individual regions could define their tasks according to their capabilities and circumstances. However, the plan provides a list of tasks remaining under exclusive

\footnotetext{
${ }^{11}$ In the Act of Minorities (2005), Silesian is not mentioned either as a national, ethnic minority or as a regional language.

${ }^{12}$ On the 2010 voivodeship elections, the RAŚ won $8.62 \%$ of the vote and gained three seats in the voivodeship sejmik, making it the fourth strongest political formation after the three large national parties, PO, PiS and SLD. PO, the victorious party, governs together with PSL, its national coalition partner and RAŚ. In April 2013, RAŚ left the coalition.
} 
national jurisdiction and declares that the Sejm and the Senate can delegate further tasks to all, or specific autonomous voivodeships.

In addition to the general rules of the planned constitution, the RAŚ has also prepared an outline for the statute of the Silesian autonomous voivodeship. This document discusses the voivodeship's institutions, administrative system and symbols, but does not define its borders, remarking only that "the Silesian Autonomous Voivodeship's territory is composed of districts which form the territory of the region on the basis of historical, cultural and economic unity" (Statut 2010, Art.3.). That these plans would bisect the current administrative borders is made clear by a previously unveiled statute plan (Gazeta Wyborcza 2010), as well as the planned headquarters for various institutions. The older plan set concrete western and eastern borders for the Voivodeship, while the current document would make Opole ${ }^{13}$ the seat of the Silesian Administrative Court, pointing at the picture of an Upper Silesian Autonomous Voivodeship which would, in theory, include the territories around Opole, but exclude the current Częstochowa area.

\section{Discussion}

The development of Upper Silesia during post-socialism represents the case of a reemerging historical region and the exploration of its newfound potential. Although hit by a structural crisis due to its reliance on traditional industries, and experiencing adverse socio-economic processes, the weight and dynamics of Upper Silesia make it one of Central Europe's most interesting and most vibrant regions. It is fair to say that no other region except national capitals have as much potential to play a prominent role in European competition, or to establish new structures of self-governance as Upper Silesia. Further advantages could be achieved through the region's cooperation with its neighbours - Kraków in Poland and Ostrava-Karvina in Czechia. Improving infrastructural connections (the A4 and A1 motorways) and enhanced economic and political cooperation can create a cross-border cluster of development poles with outstanding potential for development and further integration.

The extent of the process, which has led to Upper Silesia's increased significance will hinge on two issues: the ability to continue its economic renewal through the balance of traditional and new approaches, and how it can find viable solutions for developing effective regional governance with a higher degree of subsidiarity. The risks of the project are also apparent. The model of competitiveness, which characterises the region, is still reliant on relatively low wages, and this might pose barriers to the development of human capital, the most important resource in modern knowledge-based societies. Pathdependent development processes have been more favourable than might be expected in an old industrial region, and exploiting virtuous legacies have met with success. However, the socio-economic consequences of restructuring still remain; new external shocks in the coal and steel sector, or long-term shifts in the automotive industry may pose new risks. Furthermore, the political pressures of centralising states and internal conflicts of interest may prevent, or even lead to the disintegration of bottom-up

\footnotetext{
${ }^{13}$ Opole was the historical capital of Upper Silesia, now it is the centre of the Opole Voivodeship.
} 
decentralisation initiatives, reversing years of progress. These systematic setbacks are nothing new in the wider region.

Nevertheless, Upper Silesia can be expected to re-emerge as a key player among Central European regions. New forms of economic adaptation and administrative integration are being explored, and it is precisely this innovative character that imbues the region with its resilience and ability to reinvent itself in an ever-changing economic, social and political landscape.

\section{REFERENCES}

Arbia, G. (2006): Spatial econometrics Springer, Berlin.

Bain, A.-McLean, H. (2013): The artistic precariat Cambridge Journal of Regions, Economy and Society 6 (1): 93-111.

Bajmócy, Z. (2012): Innovációs index kistérségi szinten. Csak játék a számokkal? In.: Bajmócy Z., Lengyel I., Málovics Gy. (szerk.): Regionális innovációs képesség, versenyképesség és fenntarthatóság pp.13-32., JATEPress, Szeged.

Baranyai, N. (2013): Regionalizáció és regionalizmus Lengyelországban Doktori disszertáció. PTE BTK Interdiszciplináris Doktori Iskola, Pécs.

Chmielewska, M.-Szajnowska-Wysocka, A. (2010): Metropolia „Silesia” - Aspiracje konurbacji Górnośląskiej Acta Geographica Silesiana 7 (1): 5-10.

Chmielewska, M. (2012): Current changes in morphology of the city center of Katowice Acta Geographica Silesiana 11 (1): 5-14.

Domański, B.-Gwosdz, K. (2009): Toward a more embedded production system? Automotive supply networks and localized capabilities in Poland Growth and Change 40 (3): 452-482.

Domański, B.-Lung, Y. (2009): Editorial: The changing face of the European periphery in the automotive industry European Urban and Regional Studies 16 (1): 5-10.

Domański, B.-Guzik, R.-Gwosdz, K.-Dej, M. (2013): The crisis and beyond: The dynamics and restructuring of the automotive industry in Poland Int. J. Automotive Technology and Management 13 (2): $151-166$.

Drobniak, A.-Kolka, M.-Skowroński, M. (2012): Transition and urban economic resilience in Poland's postindustrial cities: The case of Katowice Regions 286: 13-15.

Gazeta Wyborcza 2010 = Ruch Autonomii Śląska przedstawił projekt konstytucji dla regionu.

http://wiadomosci.gazeta.pl/Wiadomosci/2029020,81048,8142584.htm [downloaded: 13. 08. 2010]

Gál, Z.-Sass, M. (2009): Emerging new locations of business services: Offshoring in Central and Eastern Europe Regions 274: 18-22.

Goczoł, L. (2012): Transition and urban economic resilience in Poland's post-industrial towns: The case of Bytom Regions 286: 15-17.

Gorzelak, G. (2005): Weryfikacja struktury celów, prorytetów oraz kierunków działań NSRR na lata 2007-2013 MGiP, Warszawa.

Gwosdz, K. (2014): Pomiędzy stara a nowa ścieżka rozwojowa. Mechanizmy ewolucji struktury gospodarczej $i$ przestrzennej regionu tradycyjnego przemystu na przykladzie konurbacji katowickiej po 1989 roku Uniwersytet Jagelloński w Krakowie, Instytut Geografii i Gospodarki Przestrzennej, Kraków.

Gwosdz, K.-Jarczewski, W.-Huculak, M. (2008): Polish special economic zones: Idea versus practice. Environment and Planning C: Government and Policy 26 (4): 824-840.

Gwosdz, K.-Micek, G. (2010): Spatial agglomerations in the Polish automotive industry Przeglad Geograficzny 82 (2): 159-190.

Katarzynat, G.-Ślusarczyk, B. (2010): Steel sector in Poland and its conditions after accession to the European Union Annales Universitatis Apulensis Series Oeconomica 12 (2): 570-574.

Klasik, A.-Heffner, K. (2001): Polish regional policy and the problems of Upper Silesia ten years into transformation. In: Klasik, A.-Heffner, K. (eds.): Restructuring heavy industrial regions. Some 
evidence from Scotland and Upper Silesia pp. 11-34., Wydawnictwo Akademii Ekonomicznej im. Karola Adamieckiego, Katowice.

Koter, M.-Kulesza, M. (2003): Lengyelország határai kialakulásának földrajzi és történelmi okai In: Ábrahám B. - Gereben F. - Stekovics R. (szerk.): Nemzeti és regionális identitás Közép-Európában pp. 281-294., Pázmány Péter Katolikus Egyetem Bölcsészettudományi Kar, Piliscsaba,

Lux, G. (2008): Egy közép-európai világváros? Ipari válság és szerkezeti átalakulás Felső-Sziléziában. Területi Statisztika 48 (1): 41-56.

Lux, G. (2009): Az ipar hagyományos terei: A régi ipari térségek Tér és Társadalom 23 (4): 45-60.

Lux, G. (2010): Location differences of services and industry: A Central European dichotomy Prace Komisji Geografiii Przemyslu Polskiego Towarzystwa Geograficznego 16: 29-37.

Łobodzińska, A.-Zbiorowski, A.-Soja, M. (2012): Population trends in Polish cities - stagnation, depopulation or shrinkage? Geographical Studies (Prace Geograficzne) 2012 (130): 7-28.

Majcherkiewicz, T. (2005): Górny Śląsk - opinie regionalnych elit administracyjnych w latach dziewięćdziesiątych. In: Leszkowicz-Baczyńska, Ż. (ed.): Transgraniczność w perspektywie socjologicznej. Nowe pogranicza? pp. 261-280., Lubuskie Towarzystwo Naukowe, Zielona Góra, http://zbc.uz.zgora.pl/Content/2346/transgr.pdf [downloaded: 7. 10. 2010]

Mezei C.-Schmidt A. (2013): A lengyel regionális politika és intézményei Tér és Társadalom 27 (3): 109-125.

Micek, G.-Działek, J.-Górecki, J. (2011): The discourse and realities of offshore business services to Kraków European Planning Studies 19 (9): 1651-1668.

Mikołajec, J. (2008): Spatial restructuring of the Katowice conurbation. In: Nowak, M. - Nowosielski, M. (eds.): Declining Cities/Developing Cities: Polish and German Perspectives pp. 101-110., Instytut Zachodni, Poznań.

Murzyn-Kupisz, M.-Gwosdz, K. (2011): The changing identity of the Central European city: The case of Katowice Journal of Historical Geography 37 (1): 113-126.

Pałucha, K. (2012): Selected problems of development of the steel industry in Poland Metalurgija 51 (3): 357360.

Polko, A. (2012): Public space development in the context of urban and regional resilience Journal of Economics and Management 10: 47-58.

Polko, A. (2013): Impact of shopping malls on the functional and spatial structure of communes in the outer metropolitan zone Studia Regionalia 37: 127-140.

Projekt zmian Konsytucji Rzeczypospolitej Polskiej. Ruch Autonomii Śląska, Katowice, 2010.

http://www.autonomia.pl/n/konstytucja [downloaded: 17. 05. 2011]

Runge, J.-Kłosowski, F. (2011): Changes in population and economy in Śląskie voivodship in the context of the suburbanization process Bulletin of Geography 16 (16): 89-106.

Rechlowicz, M.-Tkocz, M. (2013): Depopulation of traditional mining regions in Central and East Europe: Case study of Upper-Silesian basin (Poland) and the Donetsk basin (Ukraine). - 1st Annual International Interdisciplinary Conference AIIC 2013. pp. 451-459., University of the Azores, Azores Islands.

Ślusarczyk, B.-Kot, S. (2011): The consolidation influence on performance results in steel industry. -Metal 2011: 20th Anniversary International Conference on Metallurgy and Materials. Conference Proceedings pp. 1-6., Brno.

Smoliński, A.-Pichlak, M. (2009): Innovation in Polish industry: The cluster concept applied to clean coal technologies in Silesia Technology in Society 31: 356-364.

Statut Organiczny Śląskiego Województwa Autonomicznego. Ruch Autonomii Śląska, Katowice, 2010. http://www.autonomia.pl/n/statut-organiczny [downloaded: 17. 05 2011].

Strategia Rozwoju Województwa Śląskiego „Śląskie 2020+” Zarząd Województwa Śląskiego, Katowice, 2013. http://www.slaskie.pl/zalaczniki/2013/07/04/1372921202/1372921250.pdf [downloaded: 21. 11. 2013]

Sucháček, J.-Krpcová, M.-Stachoňová, M.-Holešinská, L.-Adamovský, J. (2012): Transition and resilience in Czech post-industrial towns: The case of Ostrava and Karviná Regions 286: 17-19.

Szczepański, M. S.-Śliz, A. (2012): Die Bewegung für die Autonomie Schlesiens (RAŚ). - Polen-Analysen. Nr. 112. pp. 2-8. ,Deutsches Polen-Institut, Darmstadt. http://www.bpb.de/internationales/europa/polen/139912/die-bewegung-fuer-die-autonomieschlesiens-03-07-2012 [downloaded: 6. 10. 2012] 
Szczepański, M. S.-Ślęzak-Tazbir, W.-Gawron, G. (2013): Metropolia „Silesia”: aktorzy, scena i kapitały w oglądzie socjologicznym. In: Szczepański, M. S. - Gawron, G. - Rojek-Adamek, P. (eds.): Od badania do działania. Analiza trendów rozwojowych $i$ zmian gospodarczych $w$ obszarze Górnośląskiego Związku Metropolitalnego. Wyższa Szkoła Zarządzania i Nauk Społecznych im. ks. Emila Szramka w Tychach, Tychy.

Trappmann, V. (2011): Labour as entrepreneurs: The ambivalent role of labour in restructuring in the Polish steel industry Warsaw Forum of Economic Sociology 2 (4): 7-28.

Urząd Statystyczny w Katowicach: Ludność w wojewódtzwie śląskim. Stan i struktúra demograficznospołeczna. http://www.stat.gov.pl/katow/69_1148_PLK_HTML.htm [downloaded: 4. 09. 2013]

Zientara, P. (2009): Restructuring the coal mining industry. Unionism, conflict, and cooperation: Evidence from Poland Eastern European Economics 47 (1): 41-59.

www.paiz.gov.pl 